\title{
Cultivating Intentional Consciousness in Modern History Teaching
}

\author{
Fan Cuihong \\ School of Marxism \\ Jinan university \\ Jinan Shandong, P.R.China \\ sss_fanch@ujn.edu.cn
}

\begin{abstract}
Introspection is of paramount importance to individuals and nations, and it avoids recurring mistakes. In the teaching of modern history, we must first stop the way of education that develop patriotic ideas by arousing hatred; change the understanding that the disaster is brought by others; change teaching history by pouring out sadness to telling them to reflect themselves. Analyze the reason that modern China is not strong, foster students' ability to do soul-searching.
\end{abstract}

\section{Keywords—Modern Chinese History;Teaching;Introspection}

\section{INTRODUCTION}

Introspection is the ladder of human progress, no reflection will be no progress, individuals is, nation-state is no different. Introspection can not only deepen the level of understanding of the problem, but also reduce the blindness of behavior and avoid duplication of errors. Modern Chinese history is a good teaching material for patriotism education, and also a good teaching material for reflection and education. During the teaching of this course, the author pays a lot of attention on the use of reflective education and teaching methods.

For a long time, when it comes to modern Chinese history, people think it is the history of blood and fire, is the history of the Western powers aggression, is full of humiliation, dull, depression. It left us countless painful and profound lessons. Its main color is gray and black. In the face of this history of gray and black color, we do not need blindly talk and infinite hatred, but a deep selfcriticism, self-reflection, self-analysis, in a calm and objective attitude of reflection and reflection of our own, Reflect on our cultural values, our mindset, our way of doing things. Of course, including the reflection of our teaching methods.

\section{CUlTIVATE PATRIOTISM THROUGH SELF REFLECTION}

As we all know, one of the aims of our history is to educate our country. Learning modern history can cultivate patriotic feelings, study modern history, sum up the lessons of history, treat the history of the country as a mirror of their own history, cite them as a lessons, which is very meaningful. The old saying goes, "Overturn the bad country, then the new country built will be flourishing." That is: from the historical experience analysis and analysis of the reasons for the failure to consolidate the country's survival, the country can prosperous. But the reflection of these years we cultivate the patriotic concept of the way, can not say that the problem is not serious. For a long time, we cultivate patriotic ideas using hatred. That is, a talk about patriotism, talked how we are bullied by others, by how much humiliation, how others were hateful, to remember that these humiliation and disasters made by others, and then arranged a variety of Form of propaganda, to show how our people struggle with imperialism, how to revenge, or even how to play on foreign ghosts, with hatred to cultivate patriotic ideas. Treat history as hatred, people hate. The history of the educational function was distorted. Although this method is quick and easy, but not a positive sense of patriotism, patriotis $\mathrm{m}$ is not built on hating others. Patriotism based on hatred is dangerous. If you are always filled with hatred, certainly you will have bias towards others and you cannot face the future sincerely. Naturally it is difficult to deal with other people and the relation ship between other countries. It is impossible to create a harmonious society, building a harmonious international relation. We should stop the use of this kind of education and replace it with introspection.

The so-called self-reflection is through the interpretation of history, to find their own deficiencies, reflect on their own problems, and then correct them. We cannot control others and we can only develop ourselves and make ourselves stronger, which is the most fundamental thing. This is also an important basis for introspection. Of course, we cannot forget the history filled with hatred and disasters, "forgetting the past is betrayal", but there is no need to repeatedly strengthen, it should be buried in the heart, transferred into the power of national progress. We should focus on how to understand our own deficiencies, learning the strengths of others, learning and working for our nation, is patriotic, is our contributions. This turns bad things into good things. Otherwise, bad things will again lead to bad things and humans will enter a vicious circle. So what I use is the reflection of education.

In December 2014, Chinese President Xi Jinping said on the Nanjing massacre symbol of day: We held a memorial ceremony for the victims of the Nanjing massacre, is to arouse the people of every kind of longing for peace and stick, not to perpetuate 
hatred. The people of the two countries should learn from history, friendship, for the future, to contribute to the peace of mankind. This is a kind of rational glory, is a progress.

\section{THE PREMISE OF SELF REFLECTION IS TO CHANGE IDEAS}

To deepen the reflection must first eliminate a misunderstanding: Do not think that the disaster is brought by others. In the past, textbooks and propaganda often led to the impression that from the beginning of the Opium War, the invasion of China by the Western powers led to the backwardness, ignorance, corruption and impoverishment of modern China. Almost all the disaster, are caused by others single-handedly. However, it is not! China's early famous enlightenment thinker Yan Fu once asserted that China's illness is not the main responsibility of the powers of other countries, its predicament and backward are mainly from the "in side disadvantages." In other words, we should not blindly hate others, more importantly, we should find out our own reasons, and review ourselves carefully. dare to take responsibility rather than shirk responsibility. Lu Xun issued a warning in 1925: "I think the Chinese people have accumulated enough resentment," Therefore, "when inspiring their feelings, need to try to understand the rationality," "Otherwise, It is not enemies, but their own compatriots and descendants will be punished."[1] The way to reflect rationality is reflection and introspection. As Mr. Qian Liqun said: "We cannot always stay in indignation, accusations and pain, but should extract them out." [2]

To be seriously reflect must also change the attitude towards history. In general, there are two attitudes in the history. One is the type of taking woman Like Lu Xun's Xianglin Sao, no matter whom she met, she would cry: her baby is eaten by a wolf. As times goes by, people felt annoying. Individual so, the national history is no different. China has been told this tragic history, to strengthen for many years, repeated countless times, rendering people feel a bit deep hatred, full of bitter tears, a book of tragic history. Boiling blood has been said to cool instead of provoking, excited nerves have been numb. Just like when a person is beaten, when you tell others once, the spirit of is beaten again, talk more will be beaten more, during the long-term depression, memories of the pain of the past, will be detrimental to physical and mental health. pull the people into the pain memories again and again, rather than reflect on their own, and build themselves, which is not wise. And over and over again, the result of repeated talk must be pushing responsibilities to others, strengthen and continue hatred, cover their own incompetence. This is a no backbone, not responsible nation. The solution should be freed from the pain, the suffering deeply buried in the heart, wiping away tears, look up and look forward, as "meditation recorded" in the "lost 'I was hurt' complaints, This injury will disappear. "We are not talking about the talk and then talk, but a deep reflection of reflection and then reflect on.

\section{INTERPRETATION OF MODERN CHINESE HISTORY WITH SELF REFLECTION}

As for the saying goes, "difficulties build a nation", through the history of modern times, there are a lot of disasters, but we are still not strong, so to explain the modern Chinese history, we have to understand: why the injury is always we? Why we have a lot of disasters but we are still weak? Engels said: "No big historical disaster is not compensated by historical progress." [3] This judgment does not seem to apply to modern China. Ancient Greek philosopher Heraclitus said: people cannot enter the same river twice. But our nation always falls in the same place, and even drowned in the same river. Over the past 100 years we have suffered more and more severe crackdown. Sometimes we made progress, but always further step back, to compensate us, disasters come one by one, for example, the first opium war, to The Sino-Japanese War of 1894-1895 and the Peace Protocol of 1901. Some of these disasters were made to us by others, and some are led by ourselves. Why is China always beaten or backward, cannot get out of the tragedy of the cycle? This requires thinking, from the passive beaten to learn, accumulate knowledge, learn from each other. Backward will be beaten, usually under the conditions may be so, but it is not universally applicable. That is poor and backward is not the necessary condition of being beaten, or even the main reason. The expansion of ambition of imperialism is one of the reasons, in addition, we should also have a profound reflection, look for reasons from their own. Of course, a lot of reasons, a matter of opinion, such as closed-door dictatorship, government corruption, said the system behind and so on. Here again, two case studies are as follows:

The first is arrogant, the lack of modesty to the spirit of learning, do not know to learn from others. The first opium war lasted for more than two years, the Qing army in the previous battle defeated and defeated, did not play a victory, but never learned from others. Although the war made people aware of the Western ship guns cannot be blocked, but they still refused to learn. So that in the second four years after the Opium War, the Qing did not have and change, almost completely repeated past mistakes.

Second, the lack of integrity, do not keep the Convention. The Qing government, at the end of the nineteenth century, has become a member of the international community and has signed a series of treaties with western countries, though not signed voluntarily, and they are unequal, but since you have signed, you should observe. But no, the Empress Dowager Cixi and other stubborn members ignored international laws, kill foreign ministers, attack foreign embassies and consulates, resulting in extremely bad international influence. Is it not your own responsibility?

Reflective need to refer to things, in teaching I often refer to Japan as a reference, because our two countries are similar and we had similar experience. In most of the nineteenth century, Japan's encounter with China, signed a series of unequal treaties, foreign warship cruising in its river and various ports; and its small country people, lack of resources, economic backwardness, Political chaos, many aspects even worse than China. However, from 1840 to 1942, during the process of growing up, almost no people set foot on the land to fight, this is a miracle. This miracle lies in Japan because it is better at mastering the world situation, to adapt to 
the development trend of the world. The development is its pride. we are defeated in virtual proud, from the world giant into a dwarf, which is our sorrow. Emotionally, I do not like Japan, but rationally, I admire it, it should be our example. Japan become stronger and stronger by sacrificing and retake its sovereignty to build its own refulgence.

Reflection is very embarrassing, very painful. But the reflection is necessary, for college students, sometimes more important than the positive patriotic education. It is not for the exoneration of the invaders, but to let us know more clearly about the root cause of ourselves and use the right medicine, so that we will never make same mistakes.

\section{REFERENCES}

[1] Complete Works of Lu Xun（Volume 1) [M].Beijing : People's Literature Publishing House, 1981. P225-226.

[2] Qian Liqun, I cannot do more than Lu Xun [N].The Beijing News 2007-12-21 (10)

[3] K. Marx ,F. Engels ,Karl Marx and Frederick Engels,39[M].Beijing : People's Publishing House, 1974. P49. 